\title{
Halving of consumption and energy efficiency of the "Mario Pagano" National boarding school in Campobasso
}

\author{
Giada Romano $^{\mathrm{a}, 1^{*}}$, Francesco Cesare Lallo ${ }^{\mathrm{a}}$, and Francesco Mancini ${ }^{\mathrm{a}}$

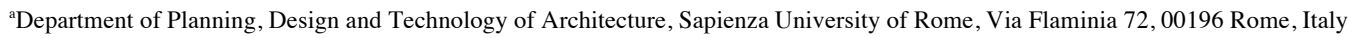

\begin{abstract}
In the national context, Italy with the Integrated National Plan for Energy and Climate (PNIEC) intends to achieve an indicative target of reducing consumption by 2030 equal to $43 \%$ of primary energy and $39.7 \%$ of final energy compared to the reference scenario of 2007 while with the National Recovery and Resilience Plan (PNRR), the ecological transition will have to be the basis of the new development model on a global scale. To start it up, it will be necessary to drastically reduce emissions of climate-altering gases in line with the objectives of the European Green Deal. Secondly, it will be necessary to improve the energy efficiency of production chains, civil settlements and public buildings and the quality of air in urban centres and water. In light of these ambitious objectives, particular attention is paid to existing buildings: this research has been focused on the is the National Boarding School "Mario Pagano", an 8,700 $\mathrm{m}^{2}$ school built in 1899 , located in the historical centre of Campobasso (Molise).

The effects of the intervention proposals have been simulated in order to evaluate energy savings and the reduction of $\mathrm{CO}_{2}$ emissions. The research is also supported by an economic evaluation that prove the economic sustainability within a period of about 15 years.
\end{abstract}

\section{Introduction}

To counter and mitigate the causes of climate change, energy sustainability is among the key objectives that EU countries aim to pursue with the European Green Deal [1] and the NextGenerationEU recovery plan [2], tools through which they aim to make Europe a climate-neutral continent by 2050 [근 $\underline{4}$.

The main instrument with which the European Union and the various Member States count on achieving these objectives are investments in energy sources, so that they are increasingly converted to Renewable Energy Sources (RES) [5] thus consistently reducing $\mathrm{CO}_{2}$ emissions [6]. For emissions to be cut by $55 \%$ by 2030 , the European Union should reduce greenhouse gas emissions from buildings by $60 \%$, their final energy consumption by $14 \%$ and energy consumption for heating and cooling by $18 \%$ [7]. It is therefore urgent for the European Union to focus on making our buildings more energy efficient, less carbon intensive throughout their life cycle and more sustainable [ $\underline{8}]$.

The National Plan for Energy and Climate (PNIEC) takes over the national implementation of these ambitious European standards, which objectives are in line with those of the European Union, putting energy efficiency and security at the forefront, as well as the use of RES and the transition to a single energy market [9], and the National Recovery and Resilience Plan (PNRR) which is an Italian transposition of the NextgenerationEU and an implementation tool to make Italy a more sustainable and inclusive country [10]. For several years, laws have already been promulgated focusing more and more attention on the need to redevelop existing buildings [11], this happened also because of the effects of climate change that for over 20 years have produced a strong and increasingly rapid rise in energy consumption in buildings [12]. For this reason, the energy consumption related to HVAC systems will continue to require more attention, especially in buildings exposed to a greater number of hours of occupation such as residential or school ones [13].

In economic terms, an increasing number of instruments are legislated and given to support interventions on the existing building stock from the energy point of view [14]. This makes it increasingly urgent to focus academia and design attention on those historic buildings, built before strict energy efficiency laws were enacted. So that, replicable intervention guidelines can be found, which comply with the directives of the public authorities responsible for the protection of these buildings but also that, at the same time, adapt them to the modern needs of use.

This research aims to focus on improving the energy performance of a boarding school, originally built at the end of the nineteenth century in Campobasso, Molise. In terms of occupancy, a building hosting a boarding school has a significant energy saving potential given by its similarity to both a school [15-16] and a residential building [17], for this reason it is an important piece of evidence.

The choice of the intervention strategies presented here stems from both the assessment of the energy savings that can be achieved and the resulting reduction in $\mathrm{CO}_{2}$ emissions.

\section{Building features and status quo}

The building, now used as primary, secondary and high school is a National Boarding School built in 1899 in Campobasso based on the Neoclassical project of roman architect Giulio De Angelis, approved in 1878. This school is a fundamental social and cultural centre for the whole region thanks to the large number of students and events hosted since its foundation in 1807, in an old monastery which was located in the same place and then demolished to build a bigger school.

\footnotetext{
${ }^{1 *}$ Corresponding author: giada.romano@uniroma1.it
} 
The complex hosts nowadays about 300 students during day time and 50 during night time and it has 2 floors for teaching, offices and student's accommodations, with and internal global surface of $8,726 \mathrm{~m}^{2}$ (while a smaller third floor is dedicated to rector's house), and about $5,000 \mathrm{~m}^{2}$ of external space for a sport's courtyard and two gardens with ancient species.

From an urban point of view, this is one of the biggest building in the city (for footprint and volume) and it is situated in the centre of the city (between Via Veneto, Via Mazzini and Corso Bucci) as an insulated block apart for the south corner that boards with a residential building.
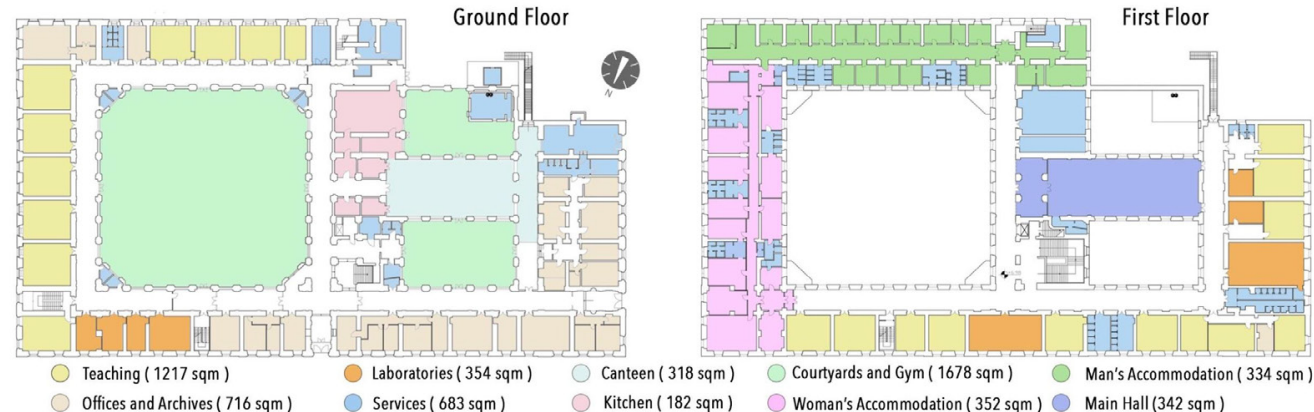

Fig. 1. Functional diagrams of the plans at present: Ground Floor and First Floor.
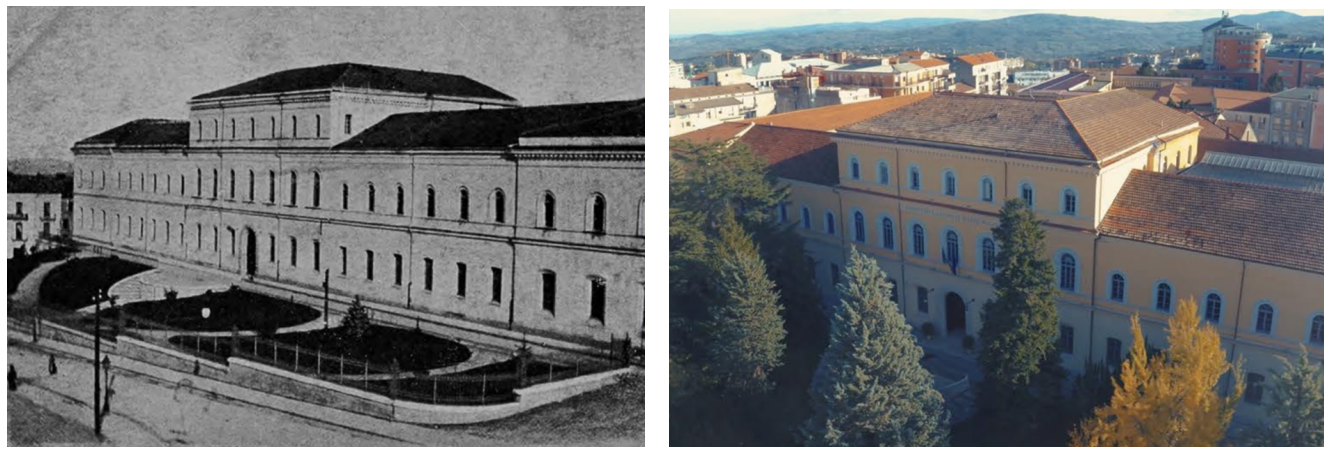

Fig. 2. North-West side (left - early '900; right - today).

Historical and cultural analysis has been a key part to understand fragility and critical points to plan interventions in a heritage listed building with one hundred years old envelope, where social memory and thermal problems coexist, requiring an accurate design.

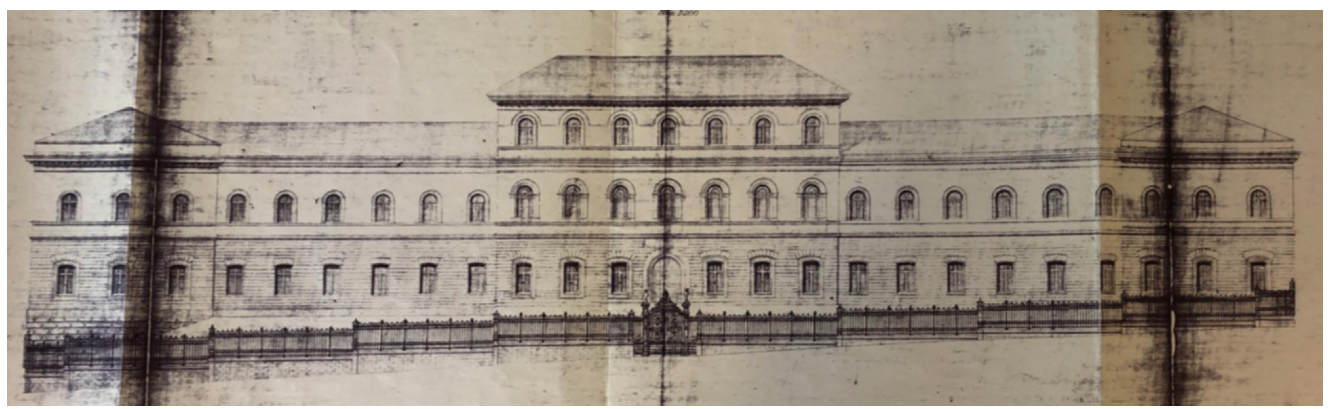

Fig. 3. Main front elevation, Arch. Giulio De Angelis, 1895, National Archive of Campobasso, b.19, f.18.

The original project included load bearing walls (with a thickness between $85 \mathrm{~cm}$ and $120 \mathrm{~cm}$ and U-value between 1.4 $\mathrm{W} / \mathrm{m}^{2} \mathrm{~K}$ and $1.81 \mathrm{~W} / \mathrm{m}^{2} \mathrm{~K}$ ) made with local stone with a triple horizontal course of bricks every $100 \mathrm{~cm}$ and plastered on internal side with natural lime based mortar and on external side with cement mortar.

The ground floor and upper levels are composed of plastered bricks vaults for the larger surface and mixed iron beams and bricks for a smaller surface, with ceramic tiles pavement. The roof is composed of wooden beams and bricks that cover a not insulated crawl space between outer space and vaulted floors that cover all the internal spaces. 

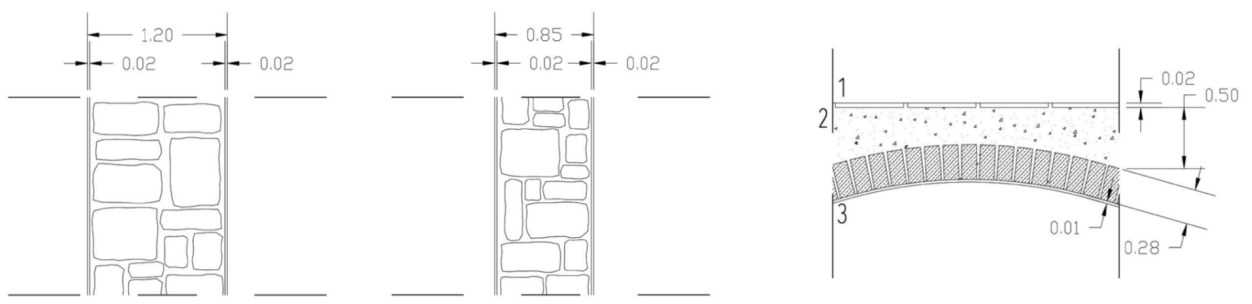

Fig. 4. Abacus of constructive elements (a) $120 \mathrm{~cm}$ bearing walls; (b) $85 \mathrm{~cm}$ bearing walls; (c) vaulted floor.

The original windows still present on the south side of the building are made of wood while the new ones, installed in the past three years, are made of insulated PVC and they have coherent forms and colours with the original windows, in order to obtain the premise from regional superintendence for architecture and landscape. The openings used can be recognized in four types, different in surfaces, number of doors and glazed parts; the new windows have a U-value of $1.4 \mathrm{~W} / \mathrm{m}^{2} \mathrm{~K}$ while old ones have a U-value of $5.9 \mathrm{~W} / \mathrm{m}^{2} \mathrm{~K}$ and surfaces between $2.53 \mathrm{~m}^{2}$ and $4.8 \mathrm{~m}^{2}$.

Table 1. Building Walls and Windows orientation $\left[\mathrm{m}^{2}\right]$ and $\mathrm{U}$-values $\left[\mathrm{W} / \mathrm{m}^{2} \mathrm{~K}\right]$.

\begin{tabular}{|c|c|c|c|c|}
\hline Wall Orientation & Total opaque area & $\begin{array}{c}\text { Thermal } \\
\text { transmittance }\end{array}$ & Total glazed area & $\begin{array}{c}\text { Thermal } \\
\text { transmittance }\end{array}$ \\
\hline $\mathrm{N}$ & $1,552.6$ & 1.42 & 162.4 & 1.4 \\
\hline $\mathrm{NE}$ & - & - & - & - \\
\hline $\mathrm{E}$ & 702.55 & 1.63 & 102.45 & 1.4 \\
\hline SE & - & - & - & - \\
\hline $\mathrm{S}$ & $1,053.5$ & 1.63 & 125.5 & 5.93 \\
\hline SW & - & - & - & - \\
\hline $\mathrm{W}$ & 526.1 & 1.81 & 64.9 & 1.4 \\
\hline NW & - & - & - & - \\
\hline Ground floor & 4,557 & 0.92 & - & - \\
\hline Roof & 4,557 & 0.97 & - & - \\
\hline
\end{tabular}

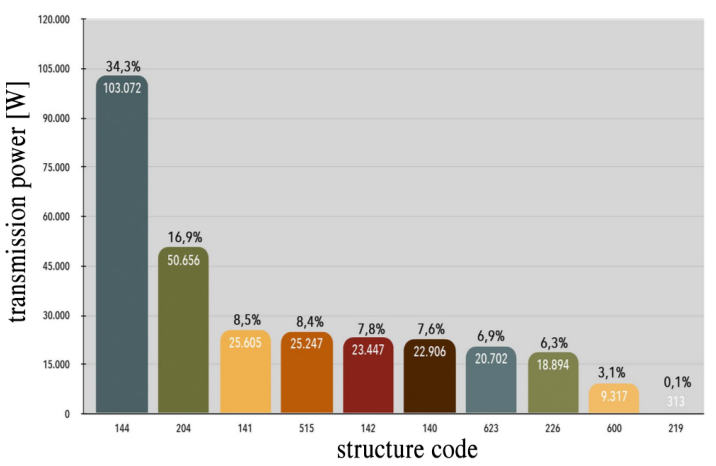

144 - not insulated stone wall $(85 \mathrm{~cm})$

204 - wooden windows (south front)

141 - not insulated stone wall $(110 \mathrm{~cm})$

515 - ground floor

142 - not insulated stone wall $(100 \mathrm{~cm})$

140 - not insulated stone wall $(120 \mathrm{~cm})$

623 - not insulated roof

226 - PVC double glazed windows (north-east-west fronts)

Total power $=398,4 \mathrm{~kW}$

Ventilation power $=98 \mathrm{~kW}$

Transmission power $=300,4 \mathrm{~kW}$

Fig. 5. Percentage incidence between dispersing structures and transmission power - before intervention

Regarding the energetic equipment of the school building, a traditional gas boiler has been replaced in 2019 with a condensing boiler that sends hot water to the heating system, composed by old cast iron radiators with reduced performance due to lower temperature in emission and long stretches of pipes from the boiler room.

Sanitary water is produced by several electric heaters placed in the toilets and sized according to needing while there is no cooling system.

Table 2. Primary energy consumption - before intervention.

\begin{tabular}{lccccc}
\hline & & Heating & Hot Water & Lighting & Total \\
\hline Renewable & {$[\mathrm{kWh} / \mathrm{y}]$} & 417 & 0 & 47,609 & 48,080 \\
Fossil & {$[\mathrm{kWh} / \mathrm{y}]$} & 663,769 & 1,411 & 197,659 & 862,839 \\
Total & {$[\mathrm{kWh} / \mathrm{y}]$} & 664,340 & 1,411 & 245,268 & 910,919 \\
Renewable fraction & {$[\%]$} & $0.1 \%$ & $0 \%$ & $19.4 \%$ & $5.3 \%$ \\
\hline
\end{tabular}




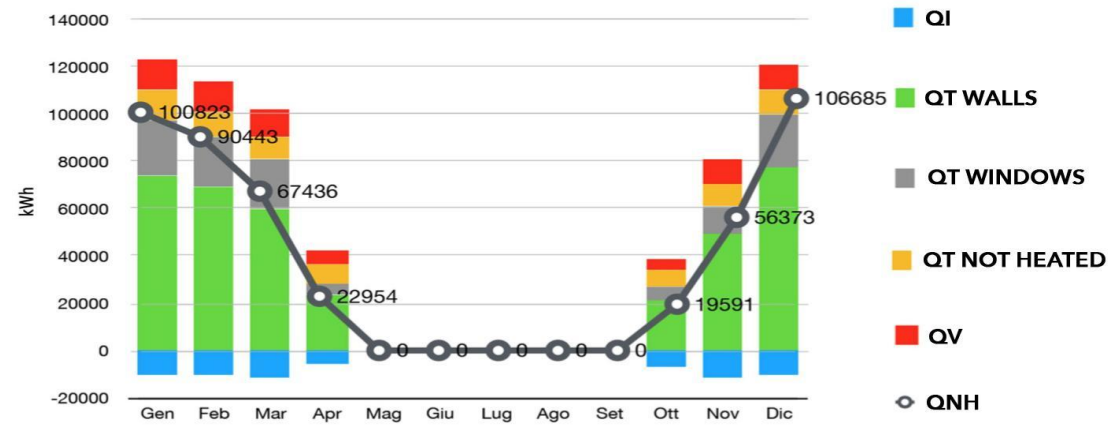

Fig. 6. Ideal energy consumption (Heating - before intervention)

As shown in figure 6 the most significant part of the energy need for heating comes from transmission through the stone walls and from original windows placed in the south side. It can be seen how during January and December the building has the highest consumption of the year.

\section{Materials and Methods}

The very first phase of research has been carried out by searching documents and original drawing in School's Archive and National Archive in Campobasso to understand constructive methods in order to develop an analytical work without destructive investigations through walls and floors, then some interviews have been conducted with technicians, workers and students to understand problems regarding internal comfort, way of using of the building, state of maintenance and consumption (through bills analysis). To confirm what was contained in the documentation found, another recognition has been carried out with direct measurement and analysis (temperature, relative humidity, air quality), specially regarding old windows and energy production and emission systems.

The methodology followed in this work includes analysis of thermo-hygrometric comfort, and an evaluation of energy performance (EP). The comfort and energy aspects have been estimated through numerical simulations, according to established procedures, technical standards and other official international references.

The thermo-hygrometric comfort has been evaluated through the indices and procedures specified in the technical standard EN 16798-1 [18].

From the point of view of energy performance, reference has been made to the technical standard EN ISO 52000-1 [19], according to which the overall energy performance of a building is the calculated or measured quantity of weighted energy necessary to meet the associated energy demand the typical use of the evaluated object: this includes the energy used for heating, cooling, domestic hot water production, lighting, transport of people or things etc.

As in the Inter-Ministerial guidelines [20] the energy performance of the building has been calculated and expressed in terms of total annual non-renewable primary energy normalized for the net conditioned area. The actual energy services of the existing building have been included, while in the refurbishment interventions, cooling and domestic hot water have been also considered. In the calculation of energy performance, the production of electricity from technologies that use RES (photovoltaic system and heat pumps) has been distributed in proportion to the electricity demand of each user. The non-renewable primary energy conversion factors of the energy carriers applied in the assessment of the EP are the Italian national values established by the above-mentioned Inter-Ministerial decree of 26 June 2015.

Based on this set of information, two building models have been built using the combination of two software: a static and a dynamic simulation tool. The first one implements the procedures of the UNI 7357/74 for the calculation of winter peak thermal loads, the Transfer Function Method (TFM) ASHRAE for the calculation of summer thermal loads and procedures of UNI/TS 11300 (UNI EN ISO 13790 national adoption) for the calculation of energy needs; the second one allows a single zone dynamic simulation and implements a finite difference simulation algorithm and it has been developed internally by the research group [21].

The building models have been validated by comparison with the data from energy bills.

The models highlight the high thermal dispersion due to the conditions of the glazed and opaque surfaces and an inadequate or nonexistent insulation layer, the reduced efficiency of the emission equipment for thermal energy composed of cast iron radiators now obsolete due to the lower temperature and too long sections of pipes from the boiler room, and the high consumption for lighting. The set of data that emerged from the energy modeling of the building put it in the category E according to energy labelling since its $\mathrm{EP}_{\mathrm{gl}, \text {,nren }}$ consumption is $197 \mathrm{kWh} / \mathrm{m}^{2} \mathrm{y}$ and $\mathrm{EP}_{\mathrm{gl}, \mathrm{ren}}$ is $10.98 \mathrm{kWh} / \mathrm{m}^{2} \mathrm{y}$ (about $5 \%$ of the total), as shown in the previous Table 2. The building at his actual status quo has $10.18 \mathrm{~kg} / \mathrm{m}^{2}$ of CO emissions. 


\section{Intervention strategies and results}

Having collected all the data about the different parts of the building and having made the necessary considerations about historical and architectural values it has been possible to develop an intervention plan with the aim of improving occupant's comfort thanks to energy refurbishment, lighting and acoustic adjustments and the introduction of new functions. Starting from the analysis the interventions have been defined in three different fields:

- In the south garden the proposal is to place a $220 \mathrm{~m}^{2}$ hydroponic greenhouse with alimentary and didactic functions, designed with passive systems (as insulated curtains and walls with thermal storage function) and low consumption active systems (as poly combustible biomass boiler and integrated systems for lighting, temperature and humidity).

- On the interior spaces the aim is to improve acoustic and lighting performances, directly connected to the purpose of having a better comprehension by the students, replacing old fluorescent and incandescent lamps with LED ones and by including a false ceiling with high acoustic absorption and upholstered chairs.

- For energy requalification the proposal is to act simultaneously on building's envelope different components and on electricity and thermal energy systems (production, storage, emission).

The external south garden represents an optimal space for greenhouse, allowing a zero consumption system that produces food for boarding students and the presence of a laboratory for primary students with the double aim of sensitize about consumptions related to food production and create modern ways of teaching in addition to traditional one.

The greenhouse is designed with passive strategies for thermal control and active strategies for emission of water, light and heating in relation with external conditions but always with the aim to maximize passive solutions thanks to sensors that can control movable insulated curtains and provide to lack of natural heating and lighting.

The analysis for lighting and acoustic performances underlines insufficient number of lamps for each classroom and high reverberation times with different emission frequencies due to high volumes and stone walls. The proposal is to replace old lamps with LED ones and with a system able to control intensity of light in relation to different activities of classrooms for the lighting system, while for acoustic performance high absorption panels and new chairs are placed permitting a reduction of reverberation by 4 times more.

Regarding the building envelope, found the impossibility to intervene on the external surface in order to maintain the original fronts, the proposed solution consists in the application of an internal layer of insulating panel in aerogel based material to ensure lightness and small loss of usable area in relation to high thermal performances. This solution is chosen also in the unheated floor to ensure insulation of the first floor. This insulating panel, coupled with glass fibres to avoid cracks on surface, has a thermal resistance of $2.01 \mathrm{~m}^{2} \mathrm{~K} / \mathrm{W}$ and a thermal conductivity at $10^{\circ} \mathrm{C}$ of $0.015 \mathrm{~W} / \mathrm{mK}$ for a thickness of $20 \mathrm{~mm}$, can resist to water and to high temperature up to $210^{\circ} \mathrm{C}$.

For glazed surfaces, it has been decided to replace old wooden windows still present on the south front with new ones used on the other three fronts. The type chosen consists of an insulated PVC frame with low emission double glazing filled with argon gas. This solution allows the windows to have a U-value of $1.4 \mathrm{~W} / \mathrm{m}^{2} \mathrm{~K}$.

Table 3. Comparison of the U-value of building components $\left[\mathrm{W} / \mathrm{m}^{2} \mathrm{~K}\right]$.

\begin{tabular}{ccc}
\hline Description & Existing situation & Intervention proposal \\
\hline Vertical building envelope & $1.42-1.82$ & $0.49-0.52$ \\
Ground floor & 0.92 & 0.45 \\
Roof & 0.97 & 0.50 \\
Original windows & 5.93 & 1.40 \\
\hline
\end{tabular}

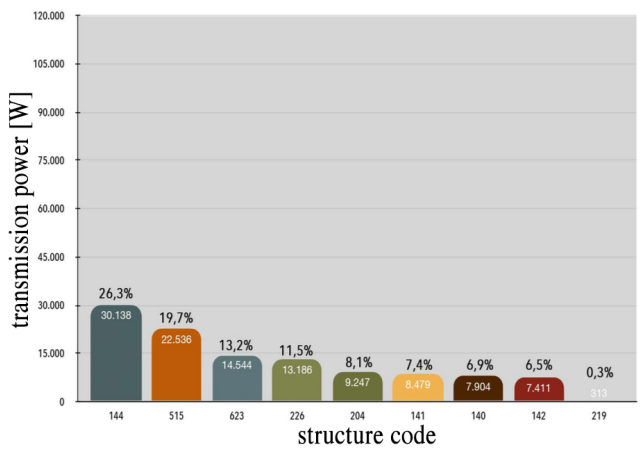

144 - insulated stone wall $(85 \mathrm{~cm})$

515 - ground floor

623 - insulated roof

226 - PVC double glazed windows (north-east-west fronts)

204 - PVC double glazed windows (south front)

141 - insulated stone wall $(110 \mathrm{~cm})$

140 - insulated stone wall $(120 \mathrm{~cm})$

142 - insulated stone wall $(100 \mathrm{~cm})$

Total power $=212,5 \mathrm{~kW}$

Ventilation power $=98 \mathrm{~kW}$

Transmission power $=114,5 \mathrm{~kW}$

Fig. 7. Percentage incidence between dispersing structures and transmission power - Intervention proposal 
Regarding the energy production and emission systems the proposal is, thanks to reduction of winter thermal loads, to replace old cast-iron radiators with radiating wall panels (in rooms with low thermal loads) and an integration of panels and fan coils (in areas with high thermal loads), in order to ensure also summer cooling in addition to heating. The emission system is integrated with a heat exchanger to permit lower consumption and working temperature. For the energy production, one of the two existing condensing boilers is integrated with a heat pump and with an accumulation system that will work also for sanitary hot water, removing old electric water heaters. The heat pump will work, during the summer period, as a production system for cooling energy while the boiler produces sanitary hot water. The condensing boiler can have a peak thermal power of $200 \mathrm{~kW}$ and the heat pump can have a thermal power of $135 \mathrm{~kW}$ and a cooling power of $115 \mathrm{~kW}$.

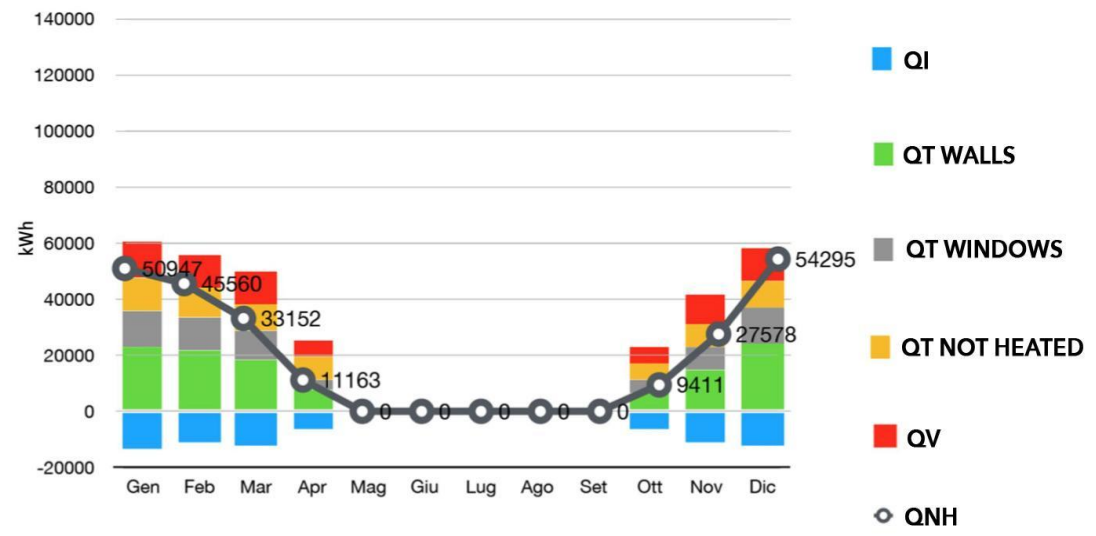

Fig. 8. Ideal energy consumption (Heating - After intervention)

Figure 8 shows the ideal energy consumption situation after the thermal insulation, the replacement of the original windows and the improvement of the systems for energy production. It can be seen that the ideal consumption can be halved in each cold month making possible a reduction of consumption and emissions but also improving the internal comfort for users.

A photovoltaic system composed of monocrystalline silicon panels has been planned on south slopes of the roof allowing, on a $715 \mathrm{~m}^{2}$ surface, an annual production of $149,000 \mathrm{kWh}$ that permit self-consumption and to supply a part of production into the national grid.

Due to interventions, it is possible to halve the transmission power through dispersant surfaces and to halve the needing of net energy for heating, ensuring better performances with significantly reduced consumption. According to energy labelling, after the interventions, the buildings belongs to category A4 since its $\mathrm{EP}_{\text {gl,nren }}$ consumption is $33.6 \mathrm{kWh} / \mathrm{m}^{2} \mathrm{y}$ and its $\mathrm{EP}_{\mathrm{gl}, \text { ren }}$ is $47 \mathrm{kWh} / \mathrm{m}^{2} \mathrm{y}$ with a $\mathrm{CO}_{2}$ emission of $1.06 \mathrm{~kg} / \mathrm{m}^{2} \mathrm{y}$ considering the aero thermal energy of the heat pump and the production of photovoltaic system.

Table 4. Primary energy consumption - after intervention.

\begin{tabular}{cccccc}
\hline & & Heating & Hot water & Lighting & Total \\
\hline Renewable & {$[\mathrm{kWh} / \mathrm{y}]$} & 115,107 & 1,004 & 66,744 & 182,855 \\
Fossil & {$[\mathrm{kWh} / \mathrm{y}]$} & 135,616 & 126 & 18,059 & 153,801 \\
Total & {$[\mathrm{kWh} / \mathrm{y}]$} & 250,724 & 1,130 & 84,802 & 336,656 \\
Renewable fraction & $\%$ & $45.9 \%$ & $88.9 \%$ & $78.7 \%$ & $54.5 \%$ \\
\hline
\end{tabular}

\subsection{Economic analysis of the interventions}

Following the definition of the interventions strategies on the building envelope and on the systems it has been possible to make a rough estimate of the investment costs in order to understand the annual savings regarding the energy consumption and the payback time compared to the interventions.

The first phase of analysis involved the estimate of annual pre and post operam consumption to understand the annual savings of energy consumption considering the costs of natural gas and electricity starting from the data collected in the bills (Table 5a-b). 
Table 5a. Estimation of annual costs based on the consumption of the various energy sources.

\begin{tabular}{lcccc}
\hline & \multicolumn{2}{c}{ Annual consumption } & \multicolumn{2}{c}{ Annual Cost } \\
\hline Electricity from the grid & 102,297 & {$[\mathrm{kWh}]$} & 23,528 & {$[€]$} \\
Natural gas & 65,823 & {$\left[\mathrm{~m}^{3}\right]$} & 55,299 & {$[€]$} \\
PV & 0 & {$[\mathrm{kWh}]$} & 0 & {$[€]$} \\
\hline
\end{tabular}

Table 5b. Expected costs based on the hypothetical consumption of the various energy sources.

\begin{tabular}{lcccccccc}
\hline & \multicolumn{2}{c}{ Annual consumption } & \multicolumn{2}{c}{ Difference } & \multicolumn{2}{c}{ Annual saving } & \multicolumn{2}{c}{ Annual Cost } \\
\hline Electricity from the grid & 14,671 & $\mathrm{kWh}$ & 87,626 & $\mathrm{kWh}$ & 20,154 & {$[€]$} & 3,374 & {$[€]$} \\
Natural gas & 12,299 & $\mathrm{~m}^{3}$ & 53,533 & $\mathrm{~m}^{3}$ & 44,968 & {$[€]$} & 10,331 & {$[€]$} \\
PV & 92,969 & $\mathrm{kWh}$ & - & $\mathrm{kWh}$ & - & {$[€]$} & 0 & {$[€]$} \\
\hline
\end{tabular}

Subsequently, the cost of each intervention has been estimated by analyzing the interested surfaces and unit prices of the elements included in the intervention proposal (Table 6).

Table 6. Expected cost for the realisation of interventions in the National boarding school [€].

\begin{tabular}{lcc}
\hline Intervention & \multicolumn{2}{c}{ Intervention Cost } \\
\hline Building Envelope & 584,000 & {$[€]$} \\
Lighting & 21,760 & {$[€]$} \\
Acoustic & 56,100 & {$[€]$} \\
Thermal energy production & 17,600 & {$[€]$} \\
Heating and Cooling & 62,972 & {$[€]$} \\
PV system & 219,030 & {$[€]$} \\
\hline TOTAL & 961,462 & {$[€]$} \\
\hline
\end{tabular}

Another aspect that should not be underestimated is linked to the necessary investments and the relative economic payback times.

There is no doubt that the overall expenditure for interventions on the building envelope and on the systems can be high, especially if compared to the economic availability within the reach of educational institutions, but it is also true that from an analysis of the return time, once after calculating the annual savings, it has been possible to define the payback times of the initial investment which can be inferred to be 15.5 years thanks to the savings in terms of energy consumption and the annual revenue for the input of electricity into the smart grid.

\section{Conclusions}

The intent of this research has been to focus attention on the importance of intervening on the existing building heritage, in Italy for the most part of a historical nature.

The urgent need to improve the energy performance of existing buildings, which are now obsolete and unsuitable for current climatic conditions, is getting stronger, as has been extensively investigated in the first part of this paper.

Furthermore, the historical value of the buildings, which also requires a constant interface with the public authorities responsible for the control and protection of the assets, no longer constitutes a brake: the methodology set out above and the choice to split the interventions among those for the building envelope, systems and outdoor spaces, allows the technicians to have a clear perspective of what can be the achievable improvements in terms of energy efficiency, and related $\mathrm{CO}_{2}$ emissions, and therefore to evaluate the interventions to be carried out in accordance with the constraints of Superintendence without compromising the historical character of the buildings.

Finally, from an economic point of view, today there are more and more incentive instruments, of an international, national and regional nature, which make it possible to obtain substantial funding for interventions to improve energy performance and efficiency and thanks to which costs be largely amortized. 


\section{References}

[1] European Commission, The European Green Deal, Bruxelles (2020)

Available online: https://ec.europa.eu/info/sites/info/files/european-green-deal-communication en.pdf (accessed on 16 November 2020)

[2] European Commission, Il Bilancio dell'UE come motore del piano per la ripresa europea, Bruxelles (2020) Available online: https://ec.europa.eu/info/sites/info/files/2020.2136 it 02.pdf (accessed on 16 November 2020)

[3] European Commission, A Clean Planet for all A European strategic long-term vision for a prosperous, modern, competitive and climate neutral economy, Bruxelles (2018). Available online: https://eur-lex.europa.eu/legalcontent/IT/TXT/PDF/?uri=CELEX:52018DC0773\&from=EN (accessed on 16 November 2020)

[4] Commissione Europea, Comunicazione della Commissione al Parlamento Europeo, al Consiglio, al Comitato Economico e Sociale Europeo e al Comitato delle Regioni - Tabella di marcia per l'energia 2050 - COM(2011) 885 final, Bruxelles (2011)

[5] European Commission, EU Climate Target Plan 2030, Bruxelles (2020). Available online: https://ec.europa.eu/commission/presscorner/api/files/attachment/866236/EU\%20Climate\%20Target\%20Plan\%2 02030\%20Building\%20a\%20modern,\%20sustainable\%20and\%20resilient\%20Europe.pdf.pdf (accessed on 16 November 2020)

[6] European Environment Agency, Trends and Projections in Europe 2020: Tracking progress towards Europe's climate and energy targets - report n 13/2020, Publications Office of the European Union, Luxemburg (2020)

[7] European Commission, Communication from the Commission to the European Parliament, the Council, the European Economic and Social Committee and the Committee of the Regions - Stepping up Europe's 2030 climate ambition - Investing in a climate-neutral future for the benefit of our people-SWD(2020) 176 final, Bruxelles (2020)

[8] European Commission, A Renovation Wave initiative for public and private buildings, Bruxelles (2020). Available online: $\quad$ https://ec.europa.eu/energy/topics/energy-efficiency/energy-efficient-buildings/renovation-wave en (accessed on 16 November 2020)

[9] Ministry of Economic Development and Ministry of Environmental and Protection of Natural Sources and the Sea, Integrated National Energy and Climate Plan (PNIEC), (2019). Available online: https://www.mise.gov.it/images/stories/documenti/PNIEC finale 17012020.pdf (accessed on 16 November 2020)

[10] Presidenza del Consiglio dei Ministri, Piano Nazionale di Ripresa e Resilienza (PNRR) (2021). Available online: https://www.governo.it/sites/governo.it/files/PNRR 0.pdf (accessed on 5 May 2021)

[11] Decreto legislativo 4 luglio 2014, n. 102 Attuazione della direttiva 2012/27/UE sull'efficienza energetica, che modifica le direttive 2009/125/CE e 2010/30/UE e abroga le direttive 2004/8/CE e 2006/32/CE. (14G00113), Gazzetta Ufficiale n. 165, (2014)

[12] F. Mancini, G.L. Basso, How climate change affects the building energy consumptions due to cooling, heating, and electricity demands of Italian residential sector, Energies, 13(2), 410 (2020)

[13] F. Mancini, F. Nardecchia, D. Groppi, F. Ruperto, C. Romeo, Indoor Environmental Quality Analysis for Optimizing Energy Consumptions Varying Air Ventilation Rates. Sustainability, 12, 482 (2020)

[14] Ministry of Economic Development and Ministry of Environmental and Protection of Natural Sources and the Sea, (2021). Criteri e modalità di concessione, erogazione e rimborso dei finanziamenti a tasso agevolato per gli interventi di efficienza energetica e di efficientamento e risparmio idrico su edifici pubblici. Available online: https://www.gazzettaufficiale.it/eli/gu/2021/04/24/98/sg/pdf (accessed on 2 May 2021)

[15] F. Ascione, N. Bianco, R. F. De Masia, F. de' Rossi, G. P. Vanoli, Energy retrofit of an educational building in the ancient centre of Benevento. Feasibility study of energy savings and respect of the historical value. Energy and Buildings, 95, 172-183 (2015).

[16] U. Berardi, M. Manca, P. Casaldaliga, F. Pich-Aguilera, From high-energy demands to nZEB: the retrofit of a school in Catalonia, Spain, Energy Procedia, 140, 141-150 (2017)

[17] L.G. Gesteira, J. Uche, L.K. de Oliveira Rodrigues, Residential Sector Energy Demand Estimation for a Singlefamily Dwelling: Dynamic Simulation and Energy Analysis, Journal of Sustainable Development of Energy, Water and Environment Systems, 9(2), 1080358 (2021)

[18] European Committee for Standardization (CEN), EN 16798-1, Energy Performance of Buildings-Part 1: Indoor Environmental Input Parameters for Design and Assessment of Energy Performance of Buildings Addressing Indoor Air Quality, Thermal Environment, Lighting and Acoustics-Module M1-6; CEN: Bruxelles, (2019)

[19] European Committee for Standardization (CEN), (2017). EN ISO 52000-1, Energy Performance of BuildingsOverarching EPB Assessment—Part 1: General Framework and Procedures; CEN: Bruxelles

[20] Italian Republic, (2015). Inter-Ministerial Decree of 26 June 2015, Applicazione delle Metodologie di Calcolo delle Prestazioni Energetiche e Definizione delle Prescrizioni e dei Requisiti Minimi Degli Edifici. Off. J. Ital. Repub., 162, 39.

[21] F. Mancini, M. Cecconi, F. De Sanctis, A. Beltotto, Energy Retrofit of a Historic Building Using Simplified Dynamic Energy Modeling, Energy Procedia, 101, 1119-1126 (2016) 